\title{
Sonodynamic effect of hematoporphyrin monomethyl ether on ligature- induced periodontitis in rats [Corrigendum]
}

\author{
Zhuang DS, Han JL, Bi LJ, et al. Drug Des Devel Ther. 2015; \\ 9:2545-2551.
}

The authors would like to make an addition to the "Acknowledgment section". The corrected section is as follows:

\section{Acknowledgments}

Financial support of this work was provided by the National Key Technology Support Program of the People's Republic of China, under grant number 2013BAI03B06. This research work was jointly supported by the Joint Specialized Research Fund for the Doctoral Program of Higher Education of the Ministry of Eduction of the People's Republic of China under grant number 20132307110018, and the Graduate Student Innovation Research Project in Harbin Medical University of the People's Republic of China under grant number YJSCX2015-32HYD.

has also been accepted for indexing on PubMed Central. The manuscript management system is completely online and includes a very quick and fair peer-review system, which is all easy to use. Visit http://www.dovepress.com/testimonials.php to read real quotes from published authors. 